\author{
dr hab. Jerzy ŚLESZYŃSKI, prof. UW \\ Wydział Nauk Ekonomicznych, Uniwersytet Warszawski \\ e-mail: sleszynski@wne.uw.edu.pl
}

DOI: $10.15290 /$ ose.2016.01.79.04

\title{
FOOTPRINTING, CZYLI MIERZENIE ŚLADU POZOSTAWIONEGO W ŚRODOWISKU
}

\begin{abstract}
Streszczenie
Celem artykułu jest przedstawienie silnych i słabych stron wskaźników z rodziny wskaźników „śladowych”, a więc wskaźników, które, podobnie jak ślad ekologiczny (Ecological Footprint), opisuja presję wywieraną na środowisko przez istniejące modele produkcji i wzorce konsumpcji. Środowisko udziela nam zasobów i przyjmuje zanieczyszczenia, ale może to czynić tylko w granicach wyznaczonych: pojemnościa, odpornością i stabilnością ekosystemów. W zakończeniu kwestia przydatności mierników „śladu” prowadzi do wskazania kierunków ich bardziej powszechnego i pożytecznego zastosowania.
\end{abstract}

Słowa kluczowe: wskaźniki śladu, ślad ekologiczny, ślad węglowy

FOOTPRINTING AS ENVIRONMENTAL IMPACT MEASURE

Summary

The paper enumerates the strengths and weaknesses of indicators belonging to the family of footprint indicators. They follow the Ecological Footprint method and describe the anthropogenic pressure on the natural environment stemming from the functioning of production models and consumption patterns. The environment provides us with resources and also absorbs pollution. However, all these benefits are available to an extent limited by the capacity, resilience and stability of ecosystems. In the conclusion of the paper, recommendations for a more frequent and productive application of footprint indicators are offered.

Key words: footprinting, ecological footprint, carbon footprint

JEL: Q56

\section{Wstęp}

Potrzeby każdego człowieka są zaspokajane dzięki składnikom środowiska przyrodniczego. Wielkość, jakość i struktura potrzeb są kształtowane przez: stan zamożności społeczeństw, poziom kultury, obyczaje i inne czynniki. Procesy produkcyjne i konsumpcję 
nadal cechuje stosunkowo wysoka intensywność zużywania zasobów naturalnych w przeliczeniu na głowę mieszkańca lub jednostkę produktu.

Eksploatacja środowiska przyrodniczego wzrasta, gdyż zwiększa się suma potrzeb i wciąż rośnie liczba ludności. Procesów tych nie da się raptownie zatrzymać, natomiast trzeba poddać je kontroli, pomiarowi i modyfikować je w zgodzie z możliwościami i właściwymi kryteriami: ekologicznymi, ekonomicznymi i społecznymi. W przeciwnym razie trzeba liczyć się z narastającymi zaburzeniami, które mogą naruszać: biosferę, gospodarkę i ład społeczny.

W krótkim horyzoncie pożądaną strategia jest łagodne pokonywanie pojawiających się trudności z pomocą doraźnych regulacji ilościowych i rynkowych, a także skutecznych porozumień międzynarodowych w odniesieniu do publicznych dóbr środowiska. W długim horyzoncie jest niezbędne zrealizowanie strategii stwarzającej warunki do dalszego rozwoju na podstawie kryteriów trwałości funkcjonowania.

Składnikami strategii muszą być znaczące zmiany w dziedzinie modeli produkcji i wzorców konsumpcji. Innowacje powinny realizować wielorakie cele, zmniejszając presję wywieraną na środowisko, a jednocześnie zapewniając rozwój w kierunku poprawy jakości życia i spójności struktur społecznych. Tylko innowacyjne rozwiązania umożliwią uruchomienie procesów dostosowawczych, które z kolei stworzą szansę adaptacji do zmiennej i niepewnej przyszłości. Realizacji tego zadania najlepiej służy strategia rozwoju trwałego i zrównoważonego [Our Common Future. World Commission on Environment and Development, 1987] ${ }^{1}$, a wśród jej narzędzi ważną rolę odgrywają wskaźniki presji na środowisko.

Przykładem popularnego wskaźnika presji jest „ślad ekologiczny pozostawiany przez człowieka w środowisku" (rozbudowane tłumaczenie oryginalnego terminu: Ecological Footprint). Do oceny intensywności gospodarowania zasobami przyrodniczymi wykorzystuje się wielkości wyrażone w jednostkach fizycznych. Wyliczenia ,śladu ekologicznego" dla polskiej gospodarki zostały przeprowadzone dla lat 1955-1997 i krótko przypomniane w tym artykule. Niestety, brakuje regularnych, krajowych badań prowadzonych w tym kierunku i wzbogacających metodologię rachunku.

Publikacje na temat, „śladu ekologicznego” zapoczątkowały badania nad zbliżonymi miernikami presji wywieranej na środowisko. Powstała cała rodzina wskaźników śladowych (footprint family), do której należą różnorodne „ślady” i mierniki intensywności eksploatacji środowiska związane $z$ różnymi rodzajami i formami użytkowania środowiska i jego poszczególnych zasobów. Obecnie najczęściej wspominanym i obliczanym miernikiem jest „ślad węglowy” (Carbon Footprint).

Koncepcja ,śladu węglowego" powstała na początku tego stulecia w ramach debat nad zmianami klimatu i monitoringiem emisji gazów cieplarnianych. W praktyce oraz

\footnotetext{
${ }^{1}$ Termin sustainable development ma w Polsce wiele błędnych interpretacji wynikających z przyjętego powszechnie tłumaczenia. W tym artykule przyjęto tłumaczenie kompromisowe: rozwój trwały i zrównoważony. Trwałość jest z całą pewnością fundamentalną i konstytutywną cechą rozwoju określanego mianem sustainable. Chodzi zarówno o poprawność pojęciową i naukową (vide: gospodarowanie zasobami odnawialnymi i związany z nim termin trwale uzyskiwanych korzyści - sustainable yield), jak i o zgodność ze słownikiem języka angielskiego. Przymiotnik 'zrównoważony' został jednak na stałe wprowadzony do polskiego piśmiennictwa i chociaż wydaje się kontrowersyjny, to nie można go pominać.
} 
w literaturze naukowej wskaźnik ten jest stosowany zarówno do oceny procesów, obiektów, produktów, jak i gospodarstw domowych i stylu życia jednostek. Studium przypadku Wydziału Chemii Uniwersytetu Warszawskiego, przytoczone w skrócie w tym artykule, pozwoli zilustrować konkretnymi danymi problem wyliczania „śladu węglowego" i praktycznej przydatności tego miernika.

Celem artykułu jest omówienie metodyki pomiaru, interpretacji i wykorzystania mierników presji na środowisko nazywanych „śladem” (footprint). Przedstawiono i krytycznie skomentowano dwa najpopularniejsze podejścia należące do tej klasy mierników rozwoju trwałego i zrównoważonego, ti.: ,ślad ekologiczny” (Ecological Footprint) oraz „ślad węglowy” (Carbon Footprint).

\section{Metodyka Ecological Footprint}

Niebywałą popularność miernik „śladu ekologicznego” (Ecological Footprint, dalej w tekście: EF) zawdzięcza bardzo licznym publikacjom dwóch autorów: Wackernagel i Rees [Rees, Wackernagel, 1994; Wackernagel, 1994; Borgström Hansson, Wackernagel, 1999; Bello i in., 1999, s. 375-390]. Postanowili oni opracować wskaźnik, który nie będzie usiłował rywalizować $z$ syntetycznymi miernikami ekonomicznymi wyrażonymi w jednostkach pieniężnych. Uznali, że presję wywieraną na środowisko najlepiej będzie wyrazić w jednostkach fizycznych. Zamiast szacować wartość zmierzonych w jednostkach fizycznych szkód wyrządzanych środowisku, skupili uwagę na ekologicznej kategorii pojemności środowiska, która w praktyce dla ludzi oznacza dostępną i niezbędną dla nich przestrzeń życiową.

Warto zauważyć, że ten aspekt wiedzy ekologicznej był i jest nadal ignorowany przez nauki ekonomiczne. Wszystkie populacje żywych organizmów napotykają w środowisku wpływ wielorakich czynników ekologicznych, które ograniczają rozwój, a więc liczebność i biomasę, a także obszar występowania danej populacji. Dynamiczny wzrost liczby ludzi zamieszkujących Ziemię stwarza wrażenie, że człowiek może ignorować pojemność środowiska, w którym żyje. Tak oczywiście nie jest. Nawet najbardziej optymistyczne prognozy nie potrafią dzisiaj odpowiedzieć na pytanie, w jaki sposób moglibyśmy wyżywić się $\mathrm{i}$ istnieć, gdyby populacja ludzka przekroczyła 40 miliardów.

$\mathrm{Z}$ antropogenicznego punktu widzenia pojemność środowiska (carrying capacity) może być rozumiana i interpretowana na dwa sposoby. Po pierwsze, jako dostępna powierzchnia, która może być zamieszkana, a przede wszystkim użytkowana w celu wytwarzania żywności i produktów potrzebnych ludziom. Po drugie, jako powierzchnia biologicznie czynna, zdolna do pochłaniania wprowadzanych do środowiska zanieczyszczeń i odpadów. W przypadku EF, oba podejścia znajdują swoje specyficzne i praktyczne zastosowanie [Ferguson, 1999, s. 149-156].

W wyniku zastosowanej metodyki EF, jednostką pomiaru sa jednostki powierzchni, najczęściej są to hektary, rzadziej kilometry kwadratowe, przeliczane następnie na głowę mieszkańca analizowanego obszaru. Liczba ludzi jest ważna, ponieważ normuje wyliczona, całkowita, eksploatowaną powierzchnię, finalnie odnosząc ją do jednego mieszkańca. W mediach i popularnych komunikatach dotyczących EF z pola widzenia znika istotne 
dla metody założenie będące podstawą pomysłu Wackernagela i Reesa. Wyliczane i dodawane hektary są hektarami hipotetycznymi (autorzy pisali o nich global hectars), a nie realnymi, to znaczy mającymi swój dokładny, materialny odpowiednik na powierzchni naszej Ziemi.

Hipotetyczność jest szczególnie widoczna w przypadku tak zwanych obszarów energetycznych, które maja przedstawiać rozmiar presji na środowisko spowodowanej użytkowaniem energii, a dokładniej nieodnawialnych nośników energii. Oczywiste uproszczenie sprowadza najpierw konsumowaną energię do emisji dwutlenku węgla. W pierwotnej wersji miernika dwutlenek węgla to jedyne zanieczyszczenie środowiska, które EF uwzględnia i następnie odzwierciedla w wartości wskaźnika. Z kolei wielkość emitowanego dwutlenku węgla jest przeliczana na obszar aktywny biologicznie na jeden z dwóch sposobów: albo jest to obszar biologicznie czynny i zdolny do pochłonięcia wyemitowanej wielkości dwutlenku węgla, albo jest to obszar upraw roślin energetycznych, które mogłyby dostarczyć energii równej jej aktualnemu zużyciu przez gospodarkę.

W praktyce rachunku EF prawie zawsze przyjmuje się pierwsze podejście: chodzi o obszar biologicznie czynny, pochłaniający antropogeniczne emisje dwutlenku węgla. Wylicza się hektary obszarów, które musiałyby pokrywać rośliny zielone - w języku ekologii są to producenci, czyli organizmy zdolne do fotosyntezy usuwającej wprowadzony do atmosfery dwutlenek węgla. W rzeczywistości rozumowanie to jest ograniczane do obszarów leśnych.

Niewątpliwie, obszary energetyczne są hipotetycznymi hektarami. Nie można udać się w podróż na ich inspekcję, ale można po wyliczeniu ich powierzchni ocenić, czy i w jakim stopniu rzeczywiste emisje przekraczają możliwości asymilacyjne realnej biosfery. Trzeba podkreślić, że ten sam sposób rozumowania odnosi się do pozostałych, wyznaczanych obszarów EF związanych z: produkcją rolniczą, produkcją drewna, tworzeniem niezbędnej człowiekowi infrastruktury.

We wspomnianym powyżej i najczęściej stosowanym podejściu zakłada się, że nieodnawialne zasoby paliw kopalnych pozostaną w najbliższej przyszłości głównym źródłem energii i emisji $\mathrm{CO}_{2}$. Emisje $\mathrm{CO}_{2}$ można mierzyć bezpośrednio, ale całkowicie zadowalającym podejściem jest zastosowanie standardowych współczynników emisyjności, określonych dla poszczególnych rodzajów nośników energii. Znając emisję $\mathrm{CO}_{2}$, będąca następstwem zużycia pewnej porcji energii, należy z kolei wyznaczyć ilość $\mathrm{CO}_{2}$, jaką może zasymilować 1 hektar lasu. W ten sposób możliwe staje się przeliczenie zużytej energii na powierzchnię asymilujących $\mathrm{CO}_{2}$ lasów² 2 .

\footnotetext{
2 Według Międzyrządowej Komisji do spraw Zmian Klimatu (Intergovernmental Panel on Climate Change), 1 ha świeżo zasadzonego lasu może pochłonąć średnio 1,42 t węgla rocznie. Według Komisji, współczynnik emisji (emission factor) dla stałych paliw kopalnych wynosi: 26 t C na TJ wytworzonej energii, dla paliw ciekłych $20 \mathrm{t} \mathrm{C/TJ}$, a dla gazu ziemnego 15,3 t C/TJ. Dzieląc 1,42 przez poszczególne czynniki emisji, otrzymujemy odpowiednio wartości: 55, 71, $93 \mathrm{GJ} / \mathrm{ha} /$ rok. Odnoszą się one do 1 ha EF dla obszaru energetycznego. Przyjęte założenia, następnie wykorzystane w obliczeniach, pochodziły z następującego źródła: [www.rprogress.org/resources/nip/ef/ef_can93.xls.sit].
} 
Warto przyjrzeć się dokładniej rachunkowi, który w odniesieniu do obszarów energetycznych został przeprowadzony ponad 10 lat temu dla polskiej gospodarki [Sleszynski, Stachowiak, 2002; Stachowiak, Śleszyński, 2002, s. 88-101]. Oczywiście obszar energetyczny został określony jako powierzchnia lasu potrzebna do absorpcji $\mathrm{CO}_{2}$ uwalnianego w wyniku procesów spalania i została ona obliczona na podstawie danych dotyczących zużycia nośników energii pierwotnej (węgla kamiennego, brunatnego, ropy naftowej, gazu ziemnego, drewna opałowego, torfu oraz energii wodnej, wiatru i słońca) w polskiej gospodarce narodowej.

Dane o emisji dwutlenku węgla w Polsce były wielkościami szacunkowymi i dotyczyły emisji powstającej w wyniku spalania różnych nośników energii. Wielkość emisji $\mathrm{CO}_{2}$ stanowiła iloczyn bieżącej konsumpcji paliw (netto) i współczynnika emisji (emission factor). Wartości współczynników emisji (tabela 1.) wyrażone w kg C na GJ wyprodukowanej energii ustalono na podstawie publikacji Międzynarodowej Agencji do spraw Energii [International Energy Agency, 2000]. Wartości współczynników emisji w kg $\mathrm{CO}_{2} / \mathrm{GJ}$ obliczono mnożąc wielkości wyrażone w $\mathrm{kg} \mathrm{C} / \mathrm{GJ}$ przez stosunek wagowy $\mathrm{CO}_{2} / \mathrm{C}$ $(44 / 12)$.

TABELA 1.

\section{Współczynniki emisji wybranych nośników energii}

\begin{tabular}{|c|c|c|}
\hline Rodzaj paliwa & $\begin{array}{c}\text { Współczynnik emisji } \\
\text { (kg C/GJ) }\end{array}$ & $\begin{array}{c}\text { Współczynnik emisji } \\
\left.\text { (kg CO }_{\mathbf{~}} / \mathbf{G J}\right)\end{array}$ \\
\hline Węgiel kamienny & 25,8 & 94,6 \\
Wegiel brunatny & 27,6 & 101,2 \\
Ropa naftowa & 20,0 & 73,3 \\
Gaz ziemny & 15,3 & 56,1 \\
Torf i drewno opałowe & 28,9 & 106 \\
\hline
\end{tabular}

Źródło: [CO 2 emission from fuel combustion 1971-1998, 2000].

Wielkość produkcji odpowiadającą 1 hektarowi obszaru energetycznego obliczono zgodnie z metodologią Wackernagela i Reesa, dzieląc zdolność absorpcyjną 1 hektara lasu, która wynosi 1,42 t C/ha/rok (5,21 t CO2/ha/rok), przez odpowiednie wspó1czynniki emisji. Otrzymano następujące wartości obejmujące jednostki energii do powierzchni (w skali jednego roku):

- $55 \mathrm{GJ} / \mathrm{ha} /$ rok dla węgla kamiennego,

- $51 \mathrm{GJ} / \mathrm{ha} /$ rok dla węgla brunatnego,

- $\quad 71 \mathrm{GJ} / \mathrm{ha} /$ rok dla ropy naftowej,

- $\quad 93 \mathrm{GJ} / \mathrm{ha} /$ rok dla gazu ziemnego,

- $49 \mathrm{GJ} / \mathrm{ha} /$ rok dla drewna opałowego i torfu.

Powyższe wartości pozwalają, dla wszystkich wymienionych, nieodnawialnych nośników energii zużytych w gospodarce w ciagu roku, wyliczyć ich powierzchniowy ekwiwalent. Hipotetyczność hektarów w rachunku podkreśla również fakt, że w przypadku pozyskiwania energii wodnej, energii wiatru i energii słonecznej 1000 GJ wyprodukowanej 
energii odpowiada wielkość 1 ha „śladu”, co ma odpowiadać hipotetycznej i uśrednionej powierzchni zajętej przez elektrownie i ich infrastrukturę [Bello i in., 1999, s. 375-390].

Wynikiem kompleksowych obliczeń jest całkowity EF uwzględniający, poza obszarami energetycznymi, również obszary: rolnicze, leśne i te związane z infrastruktura. W nowych badaniach analizą obejmuje się nie tylko obszary lądowe, ale także obszary wodne, które w pierwotnej wersji EF nie były brane pod uwagę. Obliczony EF, ewentualnie EF przeliczony na głowę mieszkańca, służy przede wszystkim porównaniu, jak mają się do siebie: $z$ jednej strony powierzchnia będąca sumą hipotetycznych obszarów niezbędnych do wytworzenia konsumowanych przez społeczeństwo dóbr, a z drugiej strony rzeczywista powierzchnia dostępna dla danego miasta, regionu lub kraju będącego przedmiotem badania.

Przewaga EF w stosunku do rzeczywistej powierzchni będącej w użytkowaniu wskazuje na deficyt, którego wielkość i trend należy interpretować jako wyraz nadmiernej presji wywieranej na środowisko. W istocie presja na środowisko spowodowana emisją $\mathrm{CO}_{2}$ przyjmuje wiele postaci, ale najłatwiej wyobrazić sobie, że nadwyżka emisji gazów cieplarnianych ponad możliwości absorpcyjne terenów zielonych musi gdzieś się podziać, a w praktyce oznacza to kumulowanie się tych gazów w atmosferze i wzrost temperatury sprzyjające ocieplaniu się klimatu, ze wszystkimi tego konsekwencjami.

Obliczenia EF prowadzi wiele ośrodków badawczych i nie zawsze ich wyniki są identyczne. Na przykład dane publikowane na temat Polski przed wielu laty zostały zweryfikowane. Badanie przeprowadzone w Warszawskim Ośrodku Ekonomii Ekologicznej wykazało, w jak dużym stopniu przeliczenia na hipotetyczne hektary było w przypadku Polski niedokładne w wyniku przyjęcia zbyt wielu upraszczających i uśredniających założeń dotyczących produktywności polskiego rolnictwa lub leśnictwa [Stachowiak, Śleszyński, 2002, s. 88-101]. Wyliczenia dla wielu krajów świata opublikowane w 1999 roku obejmowały również Polskę, wskazując EF na poziomie 4,1 hektara na osobę, pojemność środowiska 2,1 hektara na osobę, a deficyt na poziomie 2,0 hektara na osobę [Bello i in., 1999, s. 375-390]. Poniżej zamieszczono tabelę 2., przypominając własne obliczenia wykonane w Warszawskim Ośrodku Ekonomii Ekologicznej.

Pojemność środowiska zdefiniowano jako ilość ziemi przypadająca na jednego mieszkańca danego kraju. Na potrzeby oszacowania EF obliczono ją dzieląc powierzchnię Polski (ha) przez liczbę ludności. W tabeli 2. znajdują się obliczone wartości EF oraz wyznaczone wielkości deficytu ekologicznego (ecological deficit). Deficyt, ewentualnie nadwyżka, to wynik odjęcia od pojemności środowiska wyznaczonego EF. Wprowadzono korektę zalecaną przez autorów wskaźnika z uwagi na ochronę cennych przyrodniczo obszarów. Pojemność środowiska przed skonfrontowaniem z EF jest pomniejszana o normatywnie przyjęte $12 \%$, co ma oznaczać uwzględnienie hipotetycznej decyzji o zachowaniu nietkniętych obszarów leśnych ze względu na ochronę różnorodności biologicznej. 
TABELA 2.

Wskaźnik EF, pojemność środowiska i deficyt lub nadmiar ekologiczny wyznaczone dla Polski w latach 1955-1997

\begin{tabular}{|c|c|c|c|c|c|c|}
\hline Rok & $\begin{array}{c}\text { EF } \\
\text { z obsza- } \\
\text { rem energ. } \\
\text { (ha/os) }\end{array}$ & $\begin{array}{c}\text { EF bez } \\
\text { obszaru } \\
\text { energ. } \\
\text { (ha/os) }\end{array}$ & $\begin{array}{c}\text { Pojem- } \\
\text { ność } \\
\text { środowi- } \\
\text { ska } \\
\text { (ha/os) }\end{array}$ & $\begin{array}{c}\text { Minus } \\
\mathbf{1 2 \%} \text { na } \\
\text { bioróżno- } \\
\text { rodność }\end{array}$ & $\begin{array}{c}\text { Deficyt } \\
\text { ekolo- } \\
\text { giczny } \\
\text { (z obsza- } \\
\text { rem } \\
\text { energ.) } \\
\text { (ha/os) }\end{array}$ & $\begin{array}{c}\text { Nadmiar } \\
\text { (+) lub } \\
\text { deficyt (-) } \\
\text { ekologicz- } \\
\text { ny (bez } \\
\text { obszaru } \\
\text { energ.) } \\
\text { (ha/os) }\end{array}$ \\
\hline 1955 & 2,094 & 0,902 & 1,13 & 1,00 & $-0,964$ & 0,098 \\
1960 & 2,553 & 0,954 & 1,05 & 0,92 & $-1,503$ & $-0,034$ \\
1965 & 2,485 & 0,894 & 0,99 & 0,87 & $-1,495$ & $-0,024$ \\
1970 & 2,755 & 0,851 & 0,96 & 0,84 & $-1,795$ & $-0,011$ \\
1975 & 3,194 & 0,936 & 0,91 & 0,80 & $-2,284$ & $-0,136$ \\
1980 & 3,334 & 0,857 & 0,87 & 0,77 & $-2,464$ & $-0,087$ \\
1985 & 3,104 & 0,732 & 0,84 & 0,74 & $-2,264$ & 0,008 \\
1988 & 3,525 & 0,776 & 0,83 & 0,73 & $-2,695$ & $-0,046$ \\
1989 & 3,197 & 0,720 & 0,82 & 0,72 & $-2,377$ & 0,000 \\
1990 & 2,611 & 0,587 & 0,82 & 0,72 & $-1,791$ & 0,133 \\
1991 & 2,467 & 0,606 & 0,82 & 0,72 & $-1,647$ & 0,114 \\
1992 & 2,548 & 0,715 & 0,81 & 0,72 & $-1,738$ & 0,005 \\
1993 & 2,542 & 0,646 & 0,81 & 0,71 & $-1,732$ & 0,064 \\
1994 & 2,450 & 0,648 & 0,81 & 0,71 & $-1,640$ & 0,062 \\
1995 & 2,445 & 0,606 & 0,81 & 0,71 & $-1,635$ & 0,104 \\
1996 & 2,580 & 0,613 & 0,81 & 0,71 & $-1,770$ & 0,097 \\
1997 & 2,522 & 0,651 & 0,81 & 0,71 & $-1,712$ & 0,059 \\
\hline
\end{tabular}

Źródło: [Stachowiak, Śleszyński, 2002, s. 88-101].

Liczby zestawione w tabeli 2 . nie pozostawiają watpliwości, jak ogromny wpływ na końcowy wynik i wnioskowanie ma obszar energetyczny. Po pierwsze, zdecydowanie dominuje wynik oszacowania EF i nie jest to wyłącznie polska charakterystyka. Bez obszaru energetycznego problem deficytu ekologicznego praktycznie przestaje istnieć. Po drugie, udział obszaru energetycznego w wartości EF wzrasta i o ile w roku 1955 wynosił około 57\%, to w roku 1997 można było ten udział ocenić na poziomie 75\%.

W międzynarodowych publikacjach można znaleźć nowsze oszacowania EF dla Polski. Niestety, nie są one szczegółowo opisane i nie dają pewności, że zostały wyliczone z podobna precyzja, jak przypomniane, historyczne już, oszacowania. Z pewnościa pozwalają jednak zbadać trend i tendencje kształtujące się w różnych okresach. Skłaniają również do porównań z innymi krajami.

Na przykład World Wildlife Fund (WWF) ogłasza co dwa lata swoje raporty „Living Planet" o stanie naszej planety. Według WWF, obliczony dla Polski EF w 2012 roku wynosił 3,9, a w roku 2014 wzrósł do 4,1 globalnych hektarów na osobę [World Wildlife Fund, 2015]. W raporcie z roku 2012 Polska plasowała się na 45. miejscu wśród 152 państw pod względem wysokości EF. W roku 2014 wynik pomiaru EF, dokonany przez 
WWF, umieścił Polskę na miejscu 41. Dodano to tego komentarz, który miał chyba wywołać wyrzuty sumienia: gdyby wszyscy mieszkańcy Ziemi żyli eksploatując zasoby naturalne jak Polacy, to do zaspokojenia swoich potrzeb ludzkość potrzebowałaby powierzchni równej 2,4 powierzchni planet rozmiaru Ziemi.

Organizacja Global Footprint Network (GFN) również publikuje roczne raporty dotyczące pomiaru EF dla świata i poszczególnych krajów. Oficjalna strona internetowa tej organizacji pozwala zapoznać się tylko z końcowymi wyliczeniami. Wykres poniżej dotyczy Polski, dla której GFN korzystało z bazy danych ONZ ocenianych jako bardzo dobre (stąd ocena $6 \mathrm{w}$ rankingu od 1 do 6 ).

RYSUNEK 1.

Ecological Footprint per capita dla Polski w latach 1961-2011

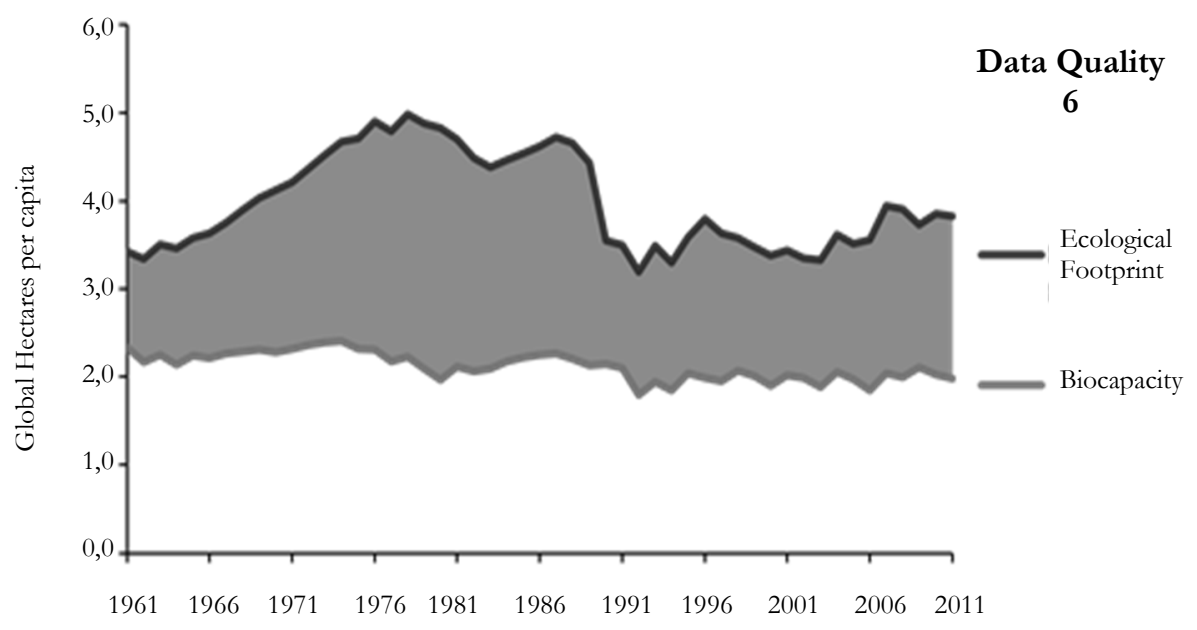

Źródło: [Global Footprint Network, 2015].

O ile obliczenia dla danego roku może cechować pewna niedokładność, to z reguły większą wiarygodność mają wyznaczone, długookresowe trendy, które pokazują tendencję zmian EF [Moran, Wackernagel, Kitzes, Goldfinger, Boutaud, 2007, s. 470-474]. Wzrostowy trend EF nie musi być wyłącznie efektem ilościowego wzrostu gospodarki. Deficyt ekologiczny może wynikać z energochłonności gospodarki i rozrzutnego gospodarowania zasobami naturalnymi, ale także ze zmian demograficznych. W przypadku Polski (rysunek 1.) duża zmienność wartości EF jest wyraźnie powiązana z kluczowymi okresami historycznymi, a następnie z okresem załamania gospodarki i kolejnymi latami dynamicznego wzrostu gospodarczego.

Dopiero szczegółowa analiza składowych EF stwarza okazję do identyfikacji źródeł największej presji [Barrett, Lewis, Simmons, 2000, s. 375-380; Kratena, 2007, s. 507-516]. Jednak wnioskowanie w tym zakresie jest przynajmniej częściowo zaburzone. Konstrukcja EF powoduje, że prawie bez wyjątku dla wszystkich krajów świata decydujący wpływ na wielkość EF mają obszary energetyczne. Ta obserwacja sygnalizuje pewną 
słabość metody. Krytycznemu omówieniu metodyki miernika EF jest poświęcona następna część artykułu.

\section{Ocena Ecological Footprint}

Cel zasadniczy - ujęcie wszystkich obszarów gospodarczej aktywności za pomocą jednej miary powierzchni - wymusił wyrażenie w hektarach rozmiaru użytkowania energii, a wybór koncepcji biologicznego pochłaniania dwutlenku węgla spowodował, że obszary energetyczne wyraźnie zdeterminowały wartość wskaźnika. Nie uniemożliwia to analizy przyczyn i oceny trendu, ale zaburzyła pewność formułowanych wniosków. To spostrzeżenie prowadzi dalej do pogłębionej oceny wskaźnika. Literatura przedmiotu, a w szczególności artykuły polemiczne publikowane przez „Ecological Economics” przyniosły bogaty materiał dowodowy na temat silnych i słabych stron miernika EF [Lawn, 2006; Śleszyński, 2009, s. 255-268].

Koncepcja EF pozwala na stosunkowo proste oszacowanie obszaru zajmowanego bezpośrednio lub wykorzystywanego przy danym poziomie rozwoju technologii, który jest niezbędny do użytkowania i przetwarzania zasobów naturalnych, konsumowanych przez: jednostkę, gospodarstwo domowe, społeczeństwo lub dowolną badaną populację. Nic więc dziwnego, że tak uniwersalne podejście wkrótce znalazło wielu entuzjastów, lecz również wielu krytyków [Barrett, Lewis, Simmons, 2000, s. 375-380; Borgström Hansson, Wackernagel, 1999, s. 2013-213; Moffatt, 2000, s. 359-362].

Najczęściej EF oblicza się dla mieszkańców w granicach państw, co według van den Bergha i Verbruggena [van den Bergh, Verbruggen, 1999, s. 61-72] nie jest słusznym podejściem. Granice państw mają bowiem charakter geopolityczny, kulturowy, a nie środowiskowy. Często dzielą naturalne obszary będące ściśle ze sobą powiązanymi ekosystemami, a więc brakuje ekologicznych uwarunkowań i charakterystyk. Bardziej trafnym byłoby więc obliczanie $\mathrm{EF}$ dla regionów naturalnych, wydzielonych na podstawie: działów wodnych, stref klimatycznych, stref glebowych itp.

Cytowani powyżej autorzy zwrócili także uwagę na fakt, że poszczególne regiony na Ziemi charakteryzują się dużą różnorodnością warunków naturalnych (gleby, klimat, rzeźba, hydrologia), co ma bezpośredni wpływ na rozmieszczenie osiedli ludzkich (np. ogromne różnice w zaludnieniu obszarów wybrzeży i pustyń). Oczywiste jest, że regiony o bardziej dogodnych warunkach naturalnych będą cechować się większą gęstością zaludnienia, a więc ilość dostępnej przestrzeni ekologicznej przypadającej na głowę mieszkańca będzie tam mniejsza.

Ponadto, państwa, których terytorium leży na obszarze o korzystnych dla człowieka warunkach naturalnych, cechują się wysokim poziomem rozwoju społeczno-gospodarczego, co jest jednoznaczne z wysokim EF. Jednak nie musi to oznaczać, że spoleczeństwa zamieszkujące te tereny są dalekie od realizacji celów trwałego rozwoju, mimo istniejącego deficytu ekologicznego. Najczęściej wynika on bowiem z dużej gęstości zaludnienia, a nie z ekstensywnej lub rabunkowej gospodarki.

Kwestią sporna, pojawiającą się w wielu opracowaniach, jest agregowanie poszczególnych składowych EF w jeden wskaźnik [Smeets, van Vuuren, 1999, s 115-130; van 
den Bergh, Verbruggen, 1999, s. 61-72]. Dodawane są bowiem obszary pełniące bardzo różne funkcje ekologiczne, obrazujące zupełnie inne rodzaje presji na środowisko. Oznacza to, że różnym kategoriom i odmiennym wzorom konsumpcji przypisuje się takie samo znaczenie w kwestii wpływu na środowisko. W rzeczywistości oddziaływanie to jest wyraźnie zróżnicowane (np. teren wykorzystywany pod zabudowę mieszkalną ma mniej destrukcyjny wpływ na środowisko, niż obszar silnie zindustrializowany).

Najwięcej kontrowersji wywołuje kategoria obszaru energetycznego. Zgodnie z czytelnymi założeniami twórców metodyki EF, kontynuacja rozwoju, czyli jego trwałość, zostanie osiagnięta wówczas, jeśli emisja $\mathrm{CO}_{2}$ nie przekroczy pojemności asymilacyjnej ekosystemów leśnych (mniej więcej 1,42 t C/ha/rok w latach dziewięćdziesiątych). Według van den Bergha i Verbruggena [van den Bergh, Verbruggen, 1999, s. 61-72], redukcja emisji do tego poziomu nie jest możliwa ani technicznie, ani ekologicznie, nie jest również uzasadniona ekonomicznie.

Założenie początkowe, przyjęte w obliczeniach $\mathrm{EF} w$ stosunku do użytkowania energii praktycznie ograniczyło listę scenariuszy do dwóch wariantów: albo hipotetyczne obszary naturalne pochłaniające dwutlenek węgla, albo obszary naturalne służące produkcji energii z biomasy. Tymczasem obie te opcje niekoniecznie są najlepsze w każdych warunkach, łatwe do zastosowania i najtańsze. Można wręcz sugerować, że często nie są ani społecznie, ani ekonomicznie do przyjęcia.

W publikowanych analizach z wykorzystaniem EF pośrednio zakłada się, że jedynym sposobem zmniejszenia ilości $\mathrm{CO}_{2}$ znajdującego się w powietrzu atmosferycznym jest zwiększanie powierzchni leśnej. Natomiast scenariusze przeciwdziałania zmianom klimatu mogą być bardzo zróżnicowane zarówno pod względem samej strategii postępowania, jak i kosztów z nimi związanych. Nie zawsze zalesianie jest najtańszą opcja. Szczególnie, jeżeli pamięta się, że obszar leśny jest wyłączony z produkcji żywności, której wciąż brakuje w wielu miejscach na świecie.

Co więcej, w obliczeniach obszaru energetycznego nie uwzględnia się rzadkości zasobów, jakimi sa paliwa kopalne oraz nie bierze się pod uwagę innych zanieczyszczeń emitowanych do atmosfery w wyniku spalania paliw kopalnych (na przykład $\mathrm{NO}_{\mathrm{x}}$ i $\mathrm{SO}_{2}$ przyczyniają się do zakwaszenia środowiska). Z pewnością powoduje to znaczne zaniżenie wartości wskaźnika presji, chociaż z drugiej strony nie bardzo wiadomo, jak zanieczyszczenia toksyczne miałyby być przeliczane na jednostkę powierzchni.

Kolejnym, kontrowersyjnym założeniem stosowanym w analizie „ekologicznego śladu" jest powiązanie danego typu ekosystemu tylko z jedna, pełniona przez niego funkcja. W związku z tym na przykład las jest traktowany jako źródło drewna wykorzystywanego w przemyśle celulozowo-papierniczym oraz jako surowiec energetyczny. Pomija się inne, bardzo ważne z punktu widzenia przyrody i człowieka funkcje lasu. Dodaje się więc do siebie hektary bez uwzględniania ich rzeczywistej, przyrodniczej roli w danym czasie i miejscu. Nie przyznaje się im żadnych wag, które mogłyby podwyższać ocenę obszarów o większym udziale ważnych i wartościowych dla ekosystemu komponentów.

Osobna grupa zastrzeżeń dotyczy interpretacji wskaźnika EF w kontekście gospodarki przestrzennej, a szerzej handlu międzynarodowego, a nawet kierunku rozwoju cywili- 
zacji. Sposób liczenia miernika narzuca swoistą interpretację wykorzystywania przestrzeni i powstawania obszarów o większym skupieniu ludności i większej aktywności gospodarczej. Miernik narzuca, że jest to interpretacja negatywnie nastawiona do rozwiązań scentralizowanych i wymagających skupienia sił i środków.

O ile zarzut o skłanianie do swoistej autarkii (sic!) jest może przesadzony, to zasadne jest zastrzeżenie, że najkorzystniej może przedstawiać się miernik dla obszaru rozległego o znikomej populacji i gospodarce mało zaawansowanej. Przykład krytyczny to bardzo niekorzystne mierniki dla wszelkich aglomeracji, chociaż wiadomo, że dzięki temu osiagnięciu cywilizacyjnemu powstała i powstaje możliwość: korzystnej koncentracji handlu, dużej skali produkcji materialnej, więzi społecznych, centrów wiedzy i kultury. Miasta, które z reguły uzyskują fatalne oceny EF, są przecież przykładem wczesnego pojawienia się intuicji co do potrzeby tworzenia centrów rozwoju, które i teraz generuje się z rozmysłem, żeby napędzać ważne dla rozwoju mechanizmy innowacji. Cywilizacyjny rozwój dokonał się między innymi dzięki kumulacji struktur miejskich dużego potencjału wytwórczego i wyspecjalizowanych profesji na małym obszarze.

Analogicznie do powyższych zastrzeżeń można sformułować zarzut pod adresem niewypowiedzianego, wprost niechętnego, traktowania korzyści komparatywnych z udziału w handlu międzynarodowym. Znane z ekonomii korzyści z międzynarodowego podziału pracy nie są tutaj w ogóle brane pod uwagę, co więcej, kraj zaangażowany w wymianę międzynarodowa jest gorzej oceniany, gdyż czerpie korzyści z innych obszarów. W nasyconej ideologicznie interpretacji oznacza to, że żyje ponad stan określony własnym obszarem, a więc rozwija się kosztem innych itp.

Symptomatyczne są oszacowania EF, w których bada się małe, uprzemysłowione kraje, ewentualnie duże miasta lub aglomeracje. Tego rodzaju obiekty, o ile tylko są otwarte na świat $\mathrm{i}$ wymianę międzynarodowa, nie maja szans, żeby wypaść dobrze w analizie „śladu ekologicznego" mierzonego wedlug zasad EF. Zarówno miasta, jak i niewielkie kraje sa ściśle uzależnione od zewnętrza. Holandia, nawet wyjątkowo dbając o własne i globalne środowisko naturalne, pozostanie w znaczaccym stopniu zależna od zagranicznych surowców i będzie konsumowała duże ilości pozyskiwanej z zewnątrz energii.

Podsumowując, interpretacja EF nie jest ani tak jednoznaczna, ani pozbawiona ideologicznego zabarwienia, jak mogłoby wydawać się z popularnych i powierzchownych wypowiedzi na temat tego wskaźnika. $Z$ drugiej strony popularność i dostępność $\mathrm{EF}$, na przykład w postaci obecnych w Internecie i bardzo licznych automatycznych kalkulatorów EF dla pojedynczego człowieka bądź gospodarstwa domowego, stwarza realną $\mathrm{i}$ trudną do przecenienia wartość informacyjną i edukacyjna.

\section{Carbon Footprint}

Naturalną kontynuacją badań nad wskaźnikami „śladu ekologicznego” było ograniczenie pola analizy do szczególnego typu oddziaływania na środowisko. Dążenie do wyrażenia za pomoca jednej miary (powierzchni, wielorakich, negatywnych oddziaływań na środowisko) zostało zastapione mniej ambitnym, ale pragmatycznie uzasadnio- 
nym pomysłem pomiaru intensywności presji w ramach ustalonych z góry. W ten sposób, kształtowana motywami badania i możliwościami pomiaru, powstała cała rodzina mierników „śladu”, których wspólną cechą jest identyfikacja presji na środowisko.

Pod względem ochrony środowiska podejście to koncentruje się na ważnych procesach i zjawiskach. Ograniczenie polega na wyborze specyficznego przedmiotu analizy, którym może być na przykład konsumpcja indywidualna, transport czy też import. Dla wybranego przedmiotu analizy, na przykład dóbr importowanych, wylicza się „ślad ekologiczny" towarzyszący ich wytworzeniu. W ten sposób można określić, w jakim stopniu dobra konsumowane w danym kraju powodują degradację środowiska w kraju eksportera. Następnym krokiem może być podjęcie ważkich decyzji dotyczących preferowanych źródeł importu i zmiana struktury importu na mniej szkodzący środowisku. Oczywiście brak działań naprawczych nie zmniejszy presji na środowisko, lecz solidarna odmowa krajów importujących może już pozytywnie wpłynąć na zachowanie kraju eksportującego dobra degradujące środowisko.

Powstało również wiele mierników presji skoncentrowanych na wybranych mediach środowiska. Stąd na przykład , ślad wodny” pokazujący wyłącznie zużycie wody przypadające na wybrany obiekt analizy, którym może być: gospodarstwo domowe, osiedle, miasto, region, kraj, lecz także proces technologiczny, określony produkt, dostarczona usługa. „Slad wodny” umożliwia identyfikuje najbardziej wodochłonnych zachowań i form aktywności gospodarczej. Rozwijane techniki analityczne, nastawione na dokonywanie pomiaru w odniesieniu do całego cyklu życia obiektów lub procesów, pozwalają uczynić pomiar intensywności zużycia wody bardziej wymownym i przydatnym dla decydentów politycznych różnego szczebla. W warunkach polskich zaobserwowano racjonalizację zachowań na poziomie gospodarstw domowych: powiązanie rachunku za wodę z zainstalowaniem wodomierzy zmniejszyło zużycie wody. Następny krok to poszukiwanie oszczędności tam, gdzie policzony „ślad wodny” wskazuje wyższe od średniego zużycie wody, prawdopodobnie powodowane lukami systemu pomiarowego bądź wadami infrastruktury.

W analogiczny sposób i z podobnymi oczekiwaniami ukształtowała się metodyka Carbon Footprint (dalej w artykule CF), [Hammond, 2007, s. 256; Aryen, Ertug, 2012]. Nazwa wskaźnika mówi o węglu, ale najczęściej analiza skupia się na emisjach gazów szklarniowych, wychodząc z założenia, że ograniczenie tego rodzaju emisji wpisuje się w oczekiwania polityki klimatycznej, a jednocześnie jest zgodne z oszczędnym użytkowaniem energii i przestawianiem gospodarek na zasoby odnawialne - obie przesłanki są oczywiście niezbywalnymi składnikami strategii rozwoju trwałego i zrównoważonego.

Podobnie jak w przypadku „śladu wodnego” i innych mierników tego typu, jest wiele wersji rachunku CF. Najogólniej można je podzielić na proste pomiary bezpośrednich emisji pochodzących z obiektu będącego przedmiotem badania oraz na metody pomiaru, które biorą również pod uwagę zewnętrzne emisje powiązane z jego funkcjonowaniem, przede wszystkim emisje powstałe poza obiektem w wyniku produkcji energii, która została zużyta przez obiekt.

Metodyka CF nie jest ostatecznie i globalnie unormowana. Z tego powodu podejścia stosowane do obliczeń CF mogą różnić się w kilku istotnych aspektach. Różnice 
zaczynają się od zakresu analizy, która, jak już wspomniano, może obejmować zarówno emisje bezpośrednie, jak i trudniejsze do identyfikacji emisje pośrednie. Następna ważna decyzja dotyczy uwzględnianych gazów, które mają wpływ na globalne ocieplenie. Określenia wymagają także granice analizowanego systemu. Prosta analiza może odnosić się do emisji w skali roku lub wybranego okresu rozliczeniowego. Jednak możliwe, a nawet wskazane, może być zastosowanie ambitnego rachunku emisji w całym cyklu życia badanego obiektu (Life Cycle Analysis - LCA). „The Publicity Available Specification 2050", publikacja stworzona przez brytyjską instytucję standaryzacyjna, była jedną z pierwszych tego typu prac i została opublikowana w roku 2008, a po trzech latach zaktualizowana. Regulowała ona metody obliczania „śladu węglowego" dla produktu z uwzględnieniem całego cyklu życia [Sinden, 2009, s. 195-203].

Do obliczeń CF wykorzystuje się dane o rzeczywistych emisjach oraz współczynniki emisji. Moga to być uśrednione wielkości emisji przypadającej na jednostkę produktu przyjmowane w szacunkach globalnych. Mogą to być także dane krajowe. W Polsce w celu ujednolicenia sposobu szacowania redukcji został opracowany i przyjęty referencyjny wskaźnik emisyjności dwutlenku węgla dla produkcji energii elektrycznej. Wynosi on: 0,812 $\mathrm{Mg} \mathrm{CO}_{2} / \mathrm{MWh}$ (według Krajowego Ośrodka Bilansowania i Zarządzania Emisjami).

Przykładem praktycznego zastosowania CF jest rachunek przeprowadzony dla Wydziału Chemii Uniwersytetu Warszawskiego [Frączek, Śleszyński, 2015, w druku]. Przykład tym bardziej znamienny, że wśród najnowszych zaleceń wynikających z europejskich dyrektyw znajdują się wymagania dokonywania audytów środowiskowych budynków publicznych. Jednym ze składników audytu jest także wyliczanie CF z myślą o formułowaniu praktycznych zaleceń zmierzających do poprawy efektywności użytkowania energii.

Zakres analizy obejmował dane dotyczące emisji bezpośrednich wytworzonych na terenie wydziału w kotłowni wytwarzającej ciepło oraz emisji pośrednich poza obiektem związanym z produkcją energii wykorzystanej przez podmiot, jak również emisją odpadów powstających poza wydziałem w wyniku utylizacji. Celem było określenie całkowitych emisji do atmosfery, z którymi wiąże się roczna eksploatacja budynku Wydziału Chemii Uniwersytetu Warszawskiego.

W analizie uwzględniono dane dla lat 2011-2013 obejmujące: całkowite zużycie gazu do uzyskania energii cieplnej, zużycie energii elektrycznej oraz odpadów wyprodukowanych przez Wydział Chemii z podziałem na odpady laboratoryjne i komunalne. Nie włączono do rachunku emisji towarzyszących wyjazdom służbowym oraz podróżom pracowników i studentów pomiędzy domem a pracą. Były to dane trudne do oszacowania, a ich brak nie wpłyną istotnie na wynik obliczeń. Przykładowy rachunek CF dla roku 2013 pokazuje dalsza część opracowania.

Obliczenie emisji wynikającej z pozyskania energii cieplnej uwzględnia, ile energii termicznej zostało wytworzonej z wykorzystanego w roku 2013 gazu ziemnego: $292915 \mathrm{~m}^{3} * 0,0344 \mathrm{GJ} / \mathrm{m}^{3}=10076,28 \mathrm{GJ}$. Następnie, korzystając z wartości opałowej gazu ziemnego, wylicza się wielkość emisji $\mathrm{CO}_{2}$ wytworzonej bezpośrednio przez wydział. Energia cieplna zużyta przez Wydział Chemii spowodowała następujące emisje:

- $\quad 10076,28 \mathrm{GJ} * 55,82 \mathrm{~kg} \mathrm{CO} / \mathrm{GJ}=562457,95 \mathrm{~kg} \mathrm{CO} 2=562,46 \mathrm{Mg} \mathrm{CO}_{2}$. 
W przypadku energii elektrycznej skorzystano ze współczynnika emisji $950 \mathrm{~kg}$ $\mathrm{CO}_{2} / \mathrm{MWh}$ określonego w dokumencie „Polityka energetyczna Polski do 2030 roku”, który jest dokumentem uchwalonym przez Radę Ministrów w 2009 roku. Takie rozwiązanie opiera się na zasadach opisanych w normie ISO 14001 dotyczącej zarządzania środowiskowego. Energia elektryczna zużyta przez Wydział Chemii spowodowała następujące emisje poza budynkiem wydziału:

$$
\text { - } 2860 \mathrm{MWh} * 950 \mathrm{~kg} \mathrm{CO} / \mathrm{MWh}=2717000 \mathrm{~kg} \mathrm{CO}_{2}=2717,00 \mathrm{Mg} \mathrm{CO}_{2} .
$$

Emisje związane z przetwarzaniem odpadów wyprodukowanych przez Wydział Chemii wyliczono w analogiczny sposób. Każda wagowa wartość danej kategorii odpadów została przeliczona na ilość energii uzyskanej w wyniku jego spalenia, a następnie wyznaczono wielkość emisji $\mathrm{CO}_{2}$ odpowiadających tej energii. Rachunek pośrednich emisji $\mathrm{CO}_{2}$ dla poszczególnych kategorii odpadów wyglądał tak:

- $\quad$ emisje z odpadów zmieszanych: $6699.672 \mathrm{~kg} \mathrm{CO}$;

- $\quad$ emisje z odpadów papieru: $1546.472928 \mathrm{~kg} \mathrm{CO}_{2}$;

- $\quad$ emisje z odpadów chemicznych: $9996.74676 \mathrm{~kg}$.

Całkowita emisja w roku 2013 została oszacowana na 3297,70 Mg CO2. Liczba studentów wynosiła 650 osób, a liczba pracowników 294 osoby, stąd CF wyniósł 5,07 Mg $\mathrm{CO}_{2} \mathrm{w}$ przeliczeniu na jednego studenta oraz 3,49 $\mathrm{Mg} \mathrm{CO}_{2} \mathrm{w}$ przeliczeniu na jedna z 944 osób korzystających z budynku. Podobne obliczenia zostały przeprowadzone dla lat 2011-2013, a wyniki przedstawia rysunek 2.

RYSUNEK 2.

\section{Obliczenia CF (Mg CO2) per capita dla Wydziału Chemii Uniwersytetu} Warszawskiego

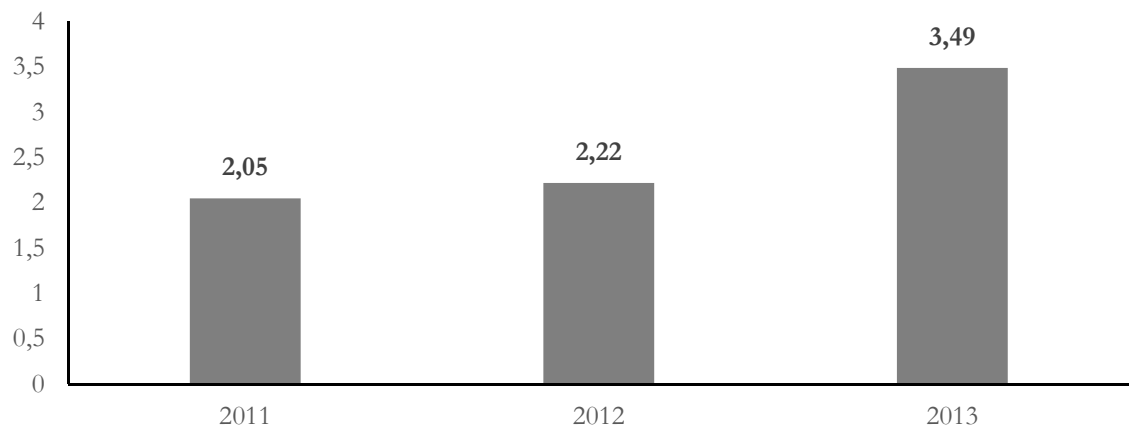

Źródło: opracowanie własne na podstawie: [Frączek, Śleszyński, 2015, w druku].

Analiza danych i wyznaczonych emisji $\mathrm{CO}_{2}$ prowadziła do wniosku, że 82,39\% całej emisji towarzyszącej eksploatacji budynku Wydziału Chemii wynikała z poboru energii elektrycznej, a 17,06\% ze zużycia gazu. Razem czyni to aż 99,45\% całkowitych emisji $\mathrm{CO}_{2}$. Zapotrzebowanie na gaz w wydziale można podzielić na: podgrzewanie wody 
(około 11\%), funkcjonowanie laboratoriów (około 4\%) oraz ogrzewanie budynku (około $85 \%$ ). Tak więc, to energia elektryczna miała największy udział w tworzeniu CF wydziału. Wiąże się to oczywiście z faktem, że w Polsce głównym surowcem wykorzystywanym do jej produkcji jest węgiel.

Na przestrzeni trzech lat (2011-2013) CF Wydziału Chemii charakteryzował bardzo mocny trend wzrostowy. W roku 2012 CF był o 8\% większy niż w roku poprzednim, natomiast w roku 2013 wzrósł o 57\% w porównaniu z rokiem 2011. Za taki stan rzeczy przede wszystkim był odpowiedzialny znaczny wzrost zapotrzebowania na energię elektryczną. Przyczyną tego jest intensywniejsze wykorzystanie posiadanego wyposażenia i laboratoriów oraz zakup nowych urządzeń klimatyzacyjnych i pomiarowych. Jednak nasuwa się podejrzenie, że rosnący CF jest również efektem niskiej i pogarszającej się efektywności wykorzystywania energii w budynku. Dopiero przeprowadzone badanie termograficzne, $z$ zastosowaniem kamery termowizyjnej, istotnie pozwoliło na zidentyfikowanie znaczących strat energetycznych w konstrukcji przedwojennego budynku [Frączek, 2014; Frączek, Śleszyński, 2015, w druku].

Największy udział w zużyciu energii elektrycznej w gmachu wydziału miała wentylacja. Na wydziale znajduje się łącznie 58 klimatyzatorów o mocy około 206 kW. Szacunkowy udział energii wykorzystanej przez wentylację w całym zużyciu energii wynosi około $35-40 \%$ w skali roku. Struktura systemu wentylacyjnego jest bardzo niejednorodna i rozproszona. Oprócz wentylacji, na wydziale energochłonne są również: serwerownia, aparaty pomiarowe oraz oświetlenie. W przeciagu ostatnich trzech lat zapotrzebowanie na energię wzrosło o $48 \%$.

Dokładna analiza stanu budynku pozwoliła na sformułowanie pozytywnych zaleceń związanych ze zmniejszeniem zużycia energii. Poprawa efektywności energetycznej będzie wymagała zastąpienia rozproszonej wentylacji systemem centralnym oraz optymalizacji pracy wentylatorów, to znaczy dostosowania charakterystyk poboru mocy do istniejącego zapotrzebowania. Kolejnym zaleceniem jest automatyzacja oświetlenia na wydziale. Sposobem na ograniczenie zużycia energii jest modernizacja światła przez zmniejszenie ilości opraw oraz zastosowanie żarówek energooszczędnych. Bardzo efektywna wydaje się również automatyzacja oświetlenia, przede wszystkim w toaletach i pomieszczeniach socjalnych.

Działania modernizacyjne powinny również dotyczyć optymalizacji zużycia energii cieplnej. Badanie termowizyjne pomogło zidentyfikować w budynku krytyczne miejsca powodujące największe straty energii. Największy ubytek ciepła jest powodowany jego przenikaniem przez ściany zewnętrzne oraz dach budynku. $Z$ tego powodu niezbędne wydaje się przeprowadzenie kompleksowej termomodernizacji Wydziału Chemii. Nadzorowanie skutecznego wprowadzania nowych rozwiązań eliminujących straty energii będzie wymagać podejścia systemowego. W takiej sytuacji celowe wydaje się wdrożenie Systemu Zarządzania Środowiskowego opartego na normach ISO 14001.

Rezultaty badania Wydziału Chemii przedstawione w niniejszej pracy potwierdzaja przydatność metody „śladu węglowego" do monitorowania sprawności energetycznej budynków użyteczności publicznej. Metoda ta może być wykorzystania zarówno do projektowania i kontroli realizacji projektów termomodernizacji budynków, jak i do 
optymalizacji i usprawniania zużycia energii elektrycznej. Podane w Deklaracji Środowiskowej Ministerstwa Środowiska plany osiagnięcia bardzo wysokiej efektywności energetycznej, sięgającej 78\% w ramach projektów modernizacji budynków publicznych, wskazują na celowość realizacji podobnych badań w odniesieniu do innych budynków uniwersyteckich.

Jednocześnie trzeba wyraźnie podkreślić, że dopiero dodatkowe badania, w tym przypadku metodą termograficzna, ujawnily przyczyny niskiej efektywności energetycznej konkretnego obiektu. Samo obliczenie CF nie daje wystarczających wskazówek, w jakich miejscach i w jakim zakresie sa potrzebne działania naprawcze mające charakter organizacyjny i techniczny.

\section{Podsumowanie}

Oczywista jest lista zalet wskaźników syntetycznych, które służą dokonaniu pomiaru presji na środowisko. Syntetyczna ocena stwarza szansę ilościowego i oceniającego wypowiadania się na temat presji, kiedy w grę wchodzą silnie ze sobą powiązane zagadnienia: gospodarcze, społeczne i środowiskowe - wspólnie tworzące obszar badawczy rozwoju trwałego i zrównoważonego. Wskaźniki syntetyczne umożliwiają śledzenie podstawowych i długookresowych trendów. Ponadto, wskaźniki syntetyczne znakomicie sprawdzają się w komunikacji społecznej oraz nadają się do porównań międzynarodowych.

Wskaźnik EF uzyskał międzynarodową renomę, która nie jest w pełni zasłużona, ale wydaje się, że korzyści z jego popularyzacji przewyższają niedogodności powodowane jego niewłaściwą i nazbyt agresywną interpretacja. Popularna interpretacja EF może stwarzać wrażenie, że posługujemy się realnymi hektarami. Przyczynia się do tego chwytliwy argument, ilu też planet rozmiaru Ziemi potrzebujemy do zaspokojenia naszych nieumiarkowanych potrzeb. W istocie "globalne hektary” wynikaja z wyliczeń opartych na hipotetycznych założeniach dotyczących biologicznej produktywności badanych obszarów i ich zdolności do pochłaniania zanieczyszczeń. Szczególnie oczywiste jest to w przypadku tak zwanych obszarów energetycznych, gdzie zużycie energii przelicza się na obszary leśne, które trzeba byłoby kultywować, aby było w stanie wchłonąć wprowadzoną do atmosfery ilość dwutlenku węgla.

Nieco inaczej przedstawia się sprawa z CF, który w zależności od potrzeb może być stosowany jako pomiar intensywności emisji gazów szklarniowych lub przyczyniać się do kompleksowego oszacowania sumy emisji związanych z pewnym procesem gospodarczym, realizowaną usługą lub funkcjonującym obiektem.

Obliczenia CF są również bardzo dobrym punktem wyjścia do identyfikacji takich niepożądanych zjawisk, jak straty energetyczne oraz niska efektywność użytkowania energii. Studium przypadku budynku Wydziału Chemii Uniwersytetu Warszawskiego skupiało się na danych łatwo dostępnych i podstawowych. Niemniej stanowi czytelną wskazówka, że konieczna jest pogłębiona analiza techniczna, na przykład z zastosowaniem kamer termowizyjnych, prowadząca do właściwego: rozpoznania, zaplanowania i przeprowadzenia różnorodnych działań naprawczych. 
Podsumowując, mierniki presji dokonujące pomiaru „śladu” nie są wolne od wad i uproszczeń. Kiedy jednak przekształcają się w mierniki intensywności użytkowania konkretnych składników środowiska, to zarówno ich interpretacja, jak i możliwości rzeczywistego wykorzystania niepomiernie wzrastają. Wydaje się, że właściwym sposobem spożytkowania wskaźników śladu, takich jak na przykład CF, jest włączanie ich do procedur dotyczących wydawania pozwoleń na gospodarcze użytkowanie zasobów środowiska. Jednocześnie znajdują one zastosowanie w audytach ekologicznych związanych z certyfikowaniem (na przykład budynków publicznych), wzbogacaja pulę informacji dostępnych w ramach etykietowania produktów, a także mogą być wykorzystywane w konstruowaniu zestawu wskaźników przekrojowych dla społeczności lokalnych.

\section{Literatura}

Aryen Y. H., Ertug A. E., 2012, Carbon and Water Footprints. Concept, metodologies and policy responces, United Nations Educational Scientific and Cultural Organization, Paris.

Barrett J., Lewis K., Simmons C., 2000, Two-feet-two approaches: a component-based model of ecological footprint, „Ecological Economics”, vol. 32.

Bello P., Onisto L., Wackernagel M., Linares A. C., Lopez Falfan I. S., Garcia J. M., Suarez Guerrero A. I, Suarez Guerrero M. G., 1999, National natural capital accounting with the ecological footprint concept, „Ecological Economics”, vol. 29.

Borgström Hansson C., Wackernagel M., 1999, Rediscovering place and accounting space: how to re-embed the buman economy, ,Ecological Economics”, vol. 29.

Europe 2007. Gross Domestic Product and Ecological Footprint, 2007, WWF European Policy Office, Brussels.

Ferguson A. R. B., 1999, The logical foundations of ecological footprints, „Environment, Development and Sustainability", vol. 1.

Global Footprint Network, 2015, http://www.footprintnetwork.org/en/index.php/ GFN/page/trends/poland/ (data wejścia: 22.07.2015).

Hammond G., 2007, Time to give due weight to the 'carbon footprint' issue, „Nature”, 445(18). http://www.rprogress.org/resources/nip/ef/ef_can93.xls.sit (data wejścia: 22.07.2015).

International Energy Agency, 2000, $\mathrm{CO}_{2}$ emission from fuel combustion.

Frączek K., Śleszyński J., 2015, Carbon Footprint for energy efficiency in public buildings, „Economic and Environmental Studies”, w druku.

Kratena K., 2007, From ecological footprint to ecological rent: An economic indicator for resource constraints, „Ecological Economics”, vol. 64.

Lawn Ph., 2006, Sustainable development: concept and indicators, [in:] Sustainable Development Indicators in Ecological Economics, Ph. Lawn (ed.), Edward Elgar, Cheltenham.

Moffatt I., 2000, Ecological Footprint and sustainable development, „Ecological Economics”, vol. 32 .

Moran D. D., Wackernagel M., Kitzes J. A., Goldfinger S. H., Boutaud A., 2007, Measuring sustainable development - Nation by nation, „Ecological Economics”, vol. 64. 
Our Common Future. World Commission on Environment and Development, 1987, Oxford University Press, Oxford.

Rees W. E., Wackernagel M., 1994, Ecological footprint and appropriated carrying capacity: measuring the natural capital requirements of the buman economy, [w:] Investing in Natural Capital: the Ecological Economics Approach to Sustainability, A. M. Jansson, M. Hammer, C. Folke, R. Costanza (eds.), Island Press, Washington DC.

Sleszynski J., Stachowiak M., 2002, Ecological Footprint: estimates for Poland and critical discussion, [in:] The 2002 International Sustainable Development Research Conference. Conference Proceedings, University of Manchester - ERP Environment, Shipley.

Smeets E. M. W., van Vuuren D. P., 2000, Ecological footprint of Benin, Bhutan, Costa Rica and the Netherlands, „Ecological Economics”, no. 34.

Stachowiak M., Śleszyński J., 2002, How big is "Ecological Footprint" of the Polish economy?, „Ekonomia”, nr 8.

Śleszyński J., 2009, Ecological Footprint as a sustainability indicator, [in:] Civilizational Competences and Regional Development in Poland, Z. B. Liberda, A. Grochowska (eds.), Warsaw University Press, Warsaw.

van den Bergh J. C. J. M., Verbruggen H., 1999, Spatial sustainability, trade and indicators: an evaluation of the 'ecological footprint', „Ecological Economics”, no. 29.

Wackernagel M., 1994, How big is our ecological footprint? Using the concept of appropriated carrying capacity for measuring sustainability, The Write Stuff, Vancouver.

World Wildlife Fund, 2015, http:/ / www.wwf.pl/co_robimy/living_planet_report/ (data wejścia: 22.07.2015). 